\title{
Effect of Anionic Group [SiO4]4-/[PO4]3- on the Luminescence Properties of Dy3+-Doped Tungstate Structural Compounds
}

\section{Ning Liu}

School of Science; School of Materials Sciences and Technology,China University of Geosciences, beijing

\section{Lefu Mei}

China University of Geosciences Beijing https://orcid.org/0000-0003-1420-2351

\section{Jianxiong Bin}

School of Materials Sciences and Technology ,China University of Geosciences, Beijing

\section{Zhijian Peng ( $\nabla$ pengzhijian@cugb.edu.cn )}

China University of Geosciences Beijing https://orcid.org/0000-0002-8241-1799

\section{Research Article}

Keywords: phosphors, scheelite structure, luminescence property, anion substitution

Posted Date: December 22nd, 2020

DOI: https://doi.org/10.21203/rs.3.rs-131871/v1

License: (9) This work is licensed under a Creative Commons Attribution 4.0 International License. Read Full License 
Effect of Anionic Group $\left[\mathrm{SiO}_{4}\right]^{4-} /\left[\mathrm{PO}_{4}\right]^{3-}$ on the Luminescence Properties of

Dy ${ }^{3+}$-Doped Tungstate Structural Compounds

Ning Liu, ${ }^{1,2}$ Lefu Mei, ${ }^{2, *}$ Jianxiong Bin, ${ }^{2}$ Zhijian Peng, ${ }^{1, *}$

${ }^{1}$ School of Science, China University of Geosciences, Beijing 100083, P.R. China.

${ }^{2}$ Beijing Key Laboratory of Materials Utilization of Nonmetallic Minerals and Solid

Wastes, National Laboratory of Mineral Materials, School of Materials Sciences and

Technology, China University of Geosciences, Beijing 100083, P.R. China

${ }^{*}$ Corresponding authors

Email: mlf@cugb.edu.cn (Lefu Mei)

Email: pengzhijian@cugb.edu.cn (Zhijian Peng) 
Abstract: The novel scheelite structures of $\mathrm{Li}_{2} \mathrm{Ca}\left(\mathrm{WO}_{4}\right)_{2}, \mathrm{Li}_{2} \mathrm{Ca}_{2}\left(\mathrm{WO}_{4}\right)\left(\mathrm{SiO}_{4}\right)$, and $\mathrm{LiCa}_{2}\left(\mathrm{WO}_{4}\right)\left(\mathrm{PO}_{4}\right)$ fluorescent materials were successfully prepared using a hightemperature solid-phase method. The compounds were characterized by XRD, EDS, and XRF. The test results showed that the substitution of $\left[\mathrm{WO}_{4}\right]^{2-}$ by $\left[\mathrm{SiO}_{4}\right]^{4-} /\left[\mathrm{PO}_{4}\right]^{3-}$ tetrahedron in tungstate had no significant influence on the crystal structure of the $\mathrm{Li}_{2} \mathrm{Ca}\left(\mathrm{WO}_{4}\right)_{2}$. When $\mathrm{Dy}^{3+}$ ions were introduced as an activator at an optimum doping concentration of $0.08 \%$ mol, all of the as-prepared phosphors generated yellow light emissions, and the emission peak was located close to $576 \mathrm{~nm}$. Replacing $\left[\mathrm{WO}_{4}\right]^{2-}$ with $\left[\mathrm{SiO}_{4}\right]^{4-} /\left[\mathrm{PO}_{4}\right]^{3-}$ tetrahedron significantly increased the luminescence of the $\mathrm{Li}_{2} \mathrm{Ca}\left(\mathrm{WO}_{4}\right)_{2}$ phosphors. In addition, the $\mathrm{LiCa}_{2}\left(\mathrm{WO}_{4}\right)\left(\mathrm{PO}_{4}\right): z \mathrm{Dy}^{3+}$ phosphors had the best luminescence properties, decay life $(\tau=0.049 \mathrm{~ms})$, and thermal stability $(87.8 \%)$.

Keywords: phosphors; scheelite structure; luminescence property; anion substitution

\section{Introduction}

Inorganic luminescent materials have historically attracted considerable attention due to their characteristics such as long decay lifetimes [1], easy preparation, low toxicity, and high luminous efficiency [2-4]. Rare earth luminescent materials have considerable application potential because of their unique $4 f$ orbit, which can be pumped to excited energy levels to emit colorful light under excitation [5, 6]. Among them, the emission of $\mathrm{Dy}^{3+}$ is mainly from the yellow-orange region $(570-600 \mathrm{~nm})$, ${ }^{4} \mathrm{~F}_{9 / 2} \rightarrow{ }^{6} \mathrm{H}_{13 / 2}$ transition [7], and ${ }^{4} \mathrm{~F}_{9 / 2} \rightarrow{ }^{6} \mathrm{H}_{15 / 2}$ transition at the blue region (470-500 nm) [8]. $\mathrm{Dy}^{3+}$ can also emit white light at a suitable yellow-blue intensity ratio [9]. The 
excitation spectrum of $\mathrm{Dy}^{3+}$ consists only of narrow $f-f$ transition lines with low oscillation intensity due to the characteristics of the $300-500 \mathrm{~nm}$ parity selection rule $\left(D y^{3+}\right.$ charge transfer absorption bands or $4 f^{8} \rightarrow 4 f^{7} 5 d$ bands below $200 \mathrm{~nm}$ ). In the matrix sensitization of $\mathrm{Dy}^{3+}$ ions, efficient energy transfer from the matrix to the $\mathrm{Dy}^{3+}$ ions is one of the most important methods of achieving efficient emission of $\mathrm{Dy}^{3+}$ ions $[10]$.

The luminescent properties of phosphors are not only affected by rare earth ions, but are also closely related to the structure and composition of the material hosts [11, 12]. Tungstate materials are considered to be effective self-activated fluorescent materials with high-absorption cross-sections [13, 14], broadband emissions [15] and high quantum efficiency $[16,17]$. Self-activating compounds can also act as matrix sensitizers to address weak $f-f$ transitions in trivalent rare earth ions. The matrix material's lattice not only affects the dopant's optical transition, but also reduces its excitation energy [18]. Among various matrix materials, phosphate has a wide band gap and high efficiency, with high thermal stability and chemical durability [19, 20]. Silicate has been widely studied as a satisfactory matrix material for fluorescent materials due to its excellent optical properties, chemical stability, and structural diversity [21, 22]. Based on these advantages, $\left[\mathrm{SiO}_{4}\right]^{4-}$ or $\left[\mathrm{PO}_{4}\right]^{3-}$ ion substitution of $\left[\mathrm{WO}_{4}\right]^{2-}$ ion to synthesize a novel scheelite structural matrix in tungstate is considered a viable and suitable luminescent material carrier [23]. Combining the stable physical and chemical properties of the matrix materials, $\mathrm{Li}_{2} \mathrm{Ca}\left(\mathrm{WO}_{4}\right)_{2}: x \mathrm{Dy}^{3+}$ and $\mathrm{Li}_{2} \mathrm{Ca}_{2}\left(\mathrm{WO}_{4}\right)\left(\mathrm{SiO}_{4}\right): y \mathrm{Dy}^{3+}$, $\mathrm{LiCa}_{2}\left(\mathrm{WO}_{4}\right)\left(\mathrm{PO}_{4}\right): z \mathrm{Dy}^{3+}$ phosphors with low energy consumption and high thermal 
stability were synthesized using a high-temperature solid-phase method, and the luminescence behavior of $\mathrm{Dy}^{3+}$ in the three hosts was studied. To verify the effect of $\left[\mathrm{SiO}_{4}\right]^{4-}$ or $\left[\mathrm{PO}_{4}\right]^{3-}$ substitution on the tungstate matrix fluorescent material's properties and elucidate the effect of anion substitution on the crystal structure, a series of comparative experiments were conducted to study the various properties after the replacement of the samples' crystal phase and anions. The luminescence properties of the doped ion samples are discussed, including excitation spectrum, emission spectrum, decay time, chromaticity diagram, and luminescence mechanism of the doping ions in three modified matrices. In addition, the thermal stability was tested to explore potential practical applications.

\section{Experimental section}

\subsection{Materials and preparation}

All of the as-prepared solid-solution samples were synthesized using a conventional high-temperature solid-phase reaction under an air atmosphere. The initial raw materials were $\mathrm{WO}_{3}$ (analytical reagent [AR]), $\mathrm{SiO}_{2}$ (AR), $\mathrm{Dy}_{2} \mathrm{O}_{3}(99.99 \%), \mathrm{CaCO}_{3}$ (AR), $\mathrm{Li}_{2} \mathrm{CO}_{3}(\mathrm{AR})$, and $\left(\mathrm{NH}_{4}\right)_{2} \mathrm{HPO}_{4}$ (AR) (excessive $\mathrm{H}_{3} \mathrm{BO}_{3}$ was added as flux) of analytic grade purity from Beijing Chemical Co. China. All of the initial reagents were weighed according to the stoichiometric ratios and mixed by grinding in an agate mortar for more than 10 minutes and pre-sintered in a muffle furnace at $550{ }^{\circ} \mathrm{C}$ for 2 hours. The sample then was cooled to room temperature and thoroughly ground again for 5 minutes. Next, different anion-regulated compounds were sintered under varying conditions. The $\mathrm{Li}_{2} \mathrm{Ca}\left(\mathrm{WO}_{4}\right)_{2}: x \mathrm{Dy}^{3+}$ sample was prepared via calcination at $1000{ }^{\circ} \mathrm{C}$ 
for 3 hours in a high-temperature tube furnace at a heating rate of $5{ }^{\circ} \mathrm{C} / \mathrm{min}$. The $\mathrm{Li}_{2} \mathrm{Ca}_{2}\left(\mathrm{WO}_{4}\right)\left(\mathrm{SiO}_{4}\right): y \mathrm{Dy}^{3+}$ phosphor was synthesized in a high-temperature tube furnace. It was then calcined at the same heating rate to $850^{\circ} \mathrm{C}$ for 3 hours, while the $\mathrm{LiCa}_{2}\left(\mathrm{WO}_{4}\right)\left(\mathrm{PO}_{4}\right): z \mathrm{Dy}^{3+}$ phosphor was calcined at $1400^{\circ} \mathrm{C}$ for 3 hours. The samples were then naturally cooled to room temperature and thoroughly ground in an agate mortar for further measurements.

\subsection{Characterization techniques}

The structural properties of the as-prepared phosphors were determined using a Bruker D8 (Germany) powder X-ray diffractometer (XRD) with $\mathrm{Cu} \mathrm{K} \alpha$ radiation $(\lambda=$ $0.15406 \mathrm{~nm}$ ) working at $40 \mathrm{kV}$ and $40 \mathrm{~mA}$ in a range from $10^{\circ}$ to $70^{\circ}$. The step scanning rate $\left(2 \theta\right.$ ranging from $5^{\circ}$ to $\left.130^{\circ}\right)$ was $2.5 \mathrm{~s} /$ step with a step size of $0.02^{\circ}$. The excitation and emission spectra of the as-prepared samples were measured using a spectrophotometer (F-4600, HITACHI, Japan) equipped with a $150 \mathrm{~W}$ Xe lamp operating at $400 \mathrm{~V}$. High-resolution transmission electron microscopy (TEM) measurements were carried out using a Tecnai G2 transmission electron microscope (TMP) operating at $200 \mathrm{kV}$. The samples' decay curves were recorded by a spectrofluorometer (HORIBA, Jobin Yvon FL3-21). The temperature-dependent PL spectra were determined on a Hitachi F-4600 spectrophotometer equipped with a selfmade heating set-up and a self-controlled electric incinerator.

\section{Results and discussion}

\subsection{Crystal structure}


The crystalline structures of the synthesized samples are shown in Figure 1. The $\mathrm{Li}_{2} \mathrm{Ca}\left(\mathrm{WO}_{4}\right)_{2}: x \mathrm{Dy}^{3+}, \mathrm{Li}_{2} \mathrm{Ca}_{2}\left(\mathrm{WO}_{4}\right)\left(\mathrm{SiO}_{4}\right): y \mathrm{Dy}^{3+}$, and $\mathrm{LiCa}_{2}\left(\mathrm{WO}_{4}\right)\left(\mathrm{PO}_{4}\right): z \mathrm{Dy}^{3+}$ phases were all pure phases. The samples' XRD patterns corresponded to calcium tungstate $\left(\mathrm{CaWO}_{4}, \mathrm{JCPDS}\right.$ no. 41-1431) and the second phases were not detected, indicating that the $\left[\mathrm{SiO}_{4}\right]^{4-} /\left[\mathrm{PO}_{4}\right]^{3-}$ successfully replaced $\left[\mathrm{WO}_{4}\right]^{2-}$ in the tungstate and was incorporated into the matrix structure. The introduction of $\mathrm{Dy}^{3+}$ ions caused no significant changes in the three matrix lattices.

\subsection{Morphology and elemental analysis}

Energy dispersive spectroscopy (EDS) and X-ray fluorescence spectroscopy (XRF) were carried out to assess the chemical composition of the compounds prepared in this study. Figure 2(a) shows a scanning electron microscope (SEM) image of the $\mathrm{Li}_{2} \mathrm{Ca}_{2}\left(\mathrm{WO}_{4}\right)\left(\mathrm{SiO}_{4}\right)$ sample and Figure 2(b) shows an EDS elemental analysis of the surface points in a rectangular region. The sample's particles were not uniform and relatively large due to agglomeration during heating. In addition, the mapping result (Figure 2(c)) demonstrated the presence of $\mathrm{Si}^{4+}$ ions in the $\mathrm{Li}_{2} \mathrm{Ca}_{2}\left(\mathrm{WO}_{4}\right)\left(\mathrm{SiO}_{4}\right)$, and the distribution of the elements including $\mathrm{Si}$ was very uniform, indicating that $\left[\mathrm{SiO}_{4}\right]^{4-}$ successfully replaced the $\left[\mathrm{WO}_{4}\right]^{2-}$ position. The samples prepared in the experiment were the $\mathrm{Li} 2 \mathrm{Ca} 2(\mathrm{WO} 4)(\mathrm{SiO} 4)$ phosphor we designed. The same examination were also carried out in the $\mathrm{LiCa}_{2}\left(\mathrm{WO}_{4}\right)\left(\mathrm{PO}_{4}\right)$ compounds. Figure 2(d) shows an agglomeration scanning electron microscope (SEM) image of the $\mathrm{Li}_{2} \mathrm{Ca}_{2}\left(\mathrm{WO}_{4}\right)\left(\mathrm{PO}_{4}\right)$ sample and Figure 2(e) shows an EDS elemental analysis of the surface points in a rectangular region. As demonstrated in Figure 2(f), the presence of elements such as $\mathrm{Ca}, \mathrm{O}, \mathrm{W}, \mathrm{P}$, 
and $\mathrm{Au}$ was detected by mapping in the $\mathrm{LiCa}_{2}\left(\mathrm{WO}_{4}\right)\left(\mathrm{PO}_{4}\right)$ compounds, and all were also uniform. The results showed that no additional impurity elements were present except for $\mathrm{Au}$ in the SEM sample holder. The elements were evenly distributed, indicating that $\left[\mathrm{PO}_{4}\right]^{4-}$ also successfully replaced the $\left[\mathrm{WO}_{4}\right]^{2-}$ position, and the sample prepared in the experiment was indeed the $\mathrm{LiCa}_{2}\left(\mathrm{WO}_{4}\right)\left(\mathrm{PO}_{4}\right)$ compound. Tables 1 and Tables 2 shows the chemical elemental analysis results of the $\mathrm{Li}_{2} \mathrm{Ca}_{2}\left(\mathrm{WO}_{4}\right)\left(\mathrm{SiO}_{4}\right)$ and $\mathrm{LiCa}_{2}\left(\mathrm{WO}_{4}\right)\left(\mathrm{PO}_{4}\right)$ samples, respectively. The data indicated that the content ratios of $\mathrm{Ca}, \mathrm{O}, \mathrm{W}$, and $\mathrm{Si}$ in the $\mathrm{Li}_{2} \mathrm{Ca}_{2}\left(\mathrm{WO}_{4}\right)\left(\mathrm{SiO}_{4}\right)$ samples were 16.2 mass\%, 38.7 mass\%, 36.6 mass $\%$, and 6.07 mass $\%$, respectively, while the content ratios of $\mathrm{Ca}, \mathrm{O}, \mathrm{W}$, and $\mathrm{P}$ in the $\mathrm{LiCa}_{2}\left(\mathrm{WO}_{4}\right)\left(\mathrm{PO}_{4}\right)$ samples were 16.0 mass $\%, 35.8$ mass $\%, 34.3$ mass $\%$, and 8.58 mass $\%$, respectively. The amount of each element was very close to the theoretical content. The results obtained by combining the EDS and XRF spectra tests clearly demonstrated that the prepared sample had a pure phase scheelite structural matrix.

3.3. Energy transfer processes involved in $\mathrm{Li}_{2} \mathrm{Ca}_{2}\left(\mathrm{WO}_{4}\right)\left(\mathrm{SiO}_{4}\right): y \mathrm{Dy}^{3+}$ and $\mathrm{LiCa}_{2}\left(\mathrm{WO}_{4}\right)\left(\mathrm{PO}_{4}\right): z \mathrm{Dy}^{3+}$ phosphors

As an important activator, $\mathrm{Dy}^{3+}$ ions have been studied in detail in many matrices $[24,25]$. For scheelite structural matrices, $\mathrm{Dy}^{3+}$ ions can also be incorporated into the crystal lattice as an effective activator. Figures 3(a) and 3(b) show the curves of the characteristic yellow emission peak $(576 \mathrm{~nm})$ and PL emission spectrum of the $\mathrm{Li}_{2} \mathrm{Ca}_{2}\left(\mathrm{WO}_{4}\right)\left(\mathrm{SiO}_{4}\right): y \mathrm{Dy}^{3+}$ and $\mathrm{LiCa}_{2}\left(\mathrm{WO}_{4}\right)\left(\mathrm{PO}_{4}\right): z \mathrm{Dy}^{3+}$ phosphors excited by $353 \mathrm{~nm}$ light with a $\mathrm{Dy}^{3+}$ ion doping concentration. Since the $\mathrm{Dy}^{3+}$ ion $4 \mathrm{f}-4 \mathrm{f}$ allowed transitions, the sample's PLE spectrum contained many peaks in the $200-450 \mathrm{~nm}$ region, including 
broadband emission peaks appearing at approximately $228,327,353,366$, and $388 \mathrm{~nm}$. At $353 \mathrm{~nm}$ excitation, the emission spectra of the $\mathrm{Li}_{2} \mathrm{Ca}_{2}\left(\mathrm{WO}_{4}\right)\left(\mathrm{SiO}_{4}\right): y \mathrm{Dy}^{3+}$ and $\mathrm{LiCa}_{2}\left(\mathrm{WO}_{4}\right)\left(\mathrm{PO}_{4}\right): z \mathrm{Dy}^{3+}$ consisted of characteristic electronic transitions of $\mathrm{Dy}^{3+}$ ions corresponding to the blue emission of the magnetic dipole ${ }^{4} \mathrm{~F}_{9 / 2} \rightarrow{ }^{6} \mathrm{H}_{15 / 2}$ (478 and 488 $\mathrm{nm})$ transitions. The yellow emission demonstrated the electric dipole ${ }^{4} \mathrm{~F}_{9 / 2} \rightarrow{ }^{6} \mathrm{~F}_{13 / 2}(576$ $\mathrm{nm})$ transitions. The energy difference between ${ }^{4} \mathrm{~F}_{9 / 2}$ and ${ }^{6} \mathrm{~F}_{3 / 2}$ is close to the energy difference between ${ }^{6} \mathrm{H}_{15 / 2}$ and ${ }^{6} \mathrm{H}_{9 / 2}$, which usually leads to cross-relaxation of the resonance energy transfer process: $\mathrm{Dy}^{3+}\left({ }^{4} \mathrm{~F}_{9 / 2}\right)+\mathrm{Dy}^{3+}\left({ }^{6} \mathrm{H}_{15 / 2}\right) \rightarrow \mathrm{Dy}^{3+}\left({ }^{6} \mathrm{~F}_{3 / 2}\right)+\mathrm{Dy}^{3+}$ $\left({ }^{6} \mathrm{H}_{9 / 2}\right)$. As shown in Figures 3(a) and 3(b), the emission intensity of the ${ }^{4} \mathrm{~F}_{9 / 2} \rightarrow{ }^{6} \mathrm{~F}_{13 / 2}$ transition first increased as the $\mathrm{Dy}^{3+}$ concentration increased, and then began to decrease at a concentration of $0.08 \%$ mol because of the effective concentration at 353 $\mathrm{nm}$ excitation. Figure 4 shows the contrast of the emission spectra of the $\mathrm{Li}_{2} \mathrm{Ca}\left(\mathrm{WO}_{4}\right)_{2}: x \mathrm{Dy}^{3+}, \mathrm{Li}_{2} \mathrm{Ca}_{2}\left(\mathrm{WO}_{4}\right)\left(\mathrm{SiO}_{4}\right): y \mathrm{Dy}^{3+}$, and $\mathrm{LiCa}_{2}\left(\mathrm{WO}_{4}\right)\left(\mathrm{PO}_{4}\right): z \mathrm{Dy}^{3+}$ samples excited by $353 \mathrm{~nm}$ light. As shown in the inset, the $\mathrm{LiCa}_{2}\left(\mathrm{WO}_{4}\right)\left(\mathrm{PO}_{4}\right): z \mathrm{Dy}^{3+}$ had the best luminescence intensity, indicating that $\left[\mathrm{PO}_{4}\right]^{3-}$ ion replacement $\left[\mathrm{WO}_{4}\right]^{2-}$ can significantly improve the performance of tungstate matrix fluorescent materials.

3.4 Effect of $\left[\mathrm{SiO}_{4}\right]^{4-}$ and $\left[\mathrm{PO}_{4}\right]^{3-}$ substituting $\left[\mathrm{WO}_{4}\right]^{2-}$ ions on the thermal stability of phosphors

Thermal stability is a key parameter to consider in practical high-power solid-state lighting applications [26-28]. The thermal stability of the $\mathrm{Li}_{2} \mathrm{Ca}\left(\mathrm{WO}_{4}\right)_{2}: 0.08 \mathrm{Dy}^{3+}$, $\mathrm{Li}_{2} \mathrm{Ca}_{2}\left(\mathrm{WO}_{4}\right)\left(\mathrm{SiO}_{4}\right): 0.08 \mathrm{Dy}^{3+}$, and $\mathrm{LiCa}_{2}\left(\mathrm{WO}_{4}\right)\left(\mathrm{PO}_{4}\right): 0.08 \mathrm{Dy}^{3+}$ samples was evaluated according to their temperature dependence. The emission spectrum obtained using 353 
$\mathrm{nm}$ wavelength light was used to produce excitation light in a temperature range of $30{ }^{\circ} \mathrm{C}$ to $300{ }^{\circ} \mathrm{C}$. Figure 5 clearly shows the dependence of the luminescence intensity of the $\mathrm{Dy}^{3+}(576 \mathrm{~nm})$ on different temperatures. As the temperature increased, the sample's luminescence intensity gradually decreased and thermal quenching occurred. The changes in the three phosphors' luminescence intensity differed from each other, indicating that the substitution of anions can significantly change the thermal stability of tungstate fluorescent materials[29]. When the temperature increased to $150{ }^{\circ} \mathrm{C}$, the thermal stability of the $\mathrm{Li}_{2} \mathrm{Ca}\left(\mathrm{WO}_{4}\right)_{2}: 0.08 \mathrm{Dy}^{3+}, \mathrm{Li}_{2} \mathrm{Ca}_{2}\left(\mathrm{WO}_{4}\right)\left(\mathrm{SiO}_{4}\right): 0.08 \mathrm{Dy}^{3+}$, and $\mathrm{LiCa}_{2}\left(\mathrm{WO}_{4}\right)\left(\mathrm{PO}_{4}\right): 0.08 \mathrm{Dy}^{3+}$ samples was $79.85 \%, 75.85 \%$, and $87.8 \%$, respectively. The luminescence intensity of the $\mathrm{LiCa}_{2}\left(\mathrm{WO}_{4}\right)\left(\mathrm{PO}_{4}\right): 0.08 \mathrm{Dy}^{3+}$ sample was less affected by temperature changes than the other two samples, indicating that the $\mathrm{LiCa}_{2}\left(\mathrm{WO}_{4}\right)\left(\mathrm{PO}_{4}\right): 0.08 \mathrm{Dy}^{3+}$ had the best thermal stability among the three kinds of fluorescent materials, and all three samples had high thermal stability.

\subsection{Fluorescence lifetime analysis}

We further investigated the effect of anion substitution on the luminescence properties and fluorescence lifetimes of the scheelite structural compounds. According to the experimental data, the attenuation curves of the three compounds exhibited a second-order exponential decay that can be fit with the following function[30]:

$$
I_{(t)}=I_{0}+A_{1} \exp \left(-t / \tau_{1}\right)+A_{2} \exp \left(-t / \tau_{2}\right)
$$


where $I_{(t)}$ is the luminescence intensity at time $t, A_{1}$ and $A_{2}$ are the fitting parameters, $\mathrm{t}$ is the time, and $\tau_{1}$ and $\tau_{2}$ are the lifetimes of the exponential components, respectively. The average lifetime $\tau^{*}$ is calculated using the following equation:

$$
\tau^{*}=\left(\mathrm{A}_{1} \tau_{1}^{2}+\mathrm{A}_{2} \tau_{2}^{2}\right) /\left(\mathrm{A}_{1} \tau_{1}+\mathrm{A}_{2} \tau_{2}\right)
$$

The $\quad \mathrm{Li}_{2} \mathrm{Ca}\left(\mathrm{WO}_{4}\right)_{2}: 0.08 \mathrm{Dy}^{3+}, \quad \mathrm{Li}_{2} \mathrm{Ca}_{2}\left(\mathrm{WO}_{4}\right)\left(\mathrm{SiO}_{4}\right): 0.08 \mathrm{Dy}^{3+}, \quad$ and $\mathrm{LiCa}_{2}\left(\mathrm{WO}_{4}\right)\left(\mathrm{PO}_{4}\right): 0.08 \mathrm{Dy}^{3+}$ samples $\left(\lambda_{\mathrm{ex}}=353 \mathrm{~nm}\right.$ and $\left.\lambda_{\mathrm{em}}=576 \mathrm{~nm}\right)$ were tested for fluorescence decay life. Figure 6 shows that the average decay time $\left(\tau^{*}\right)$ of the $\mathrm{Li}_{2} \mathrm{Ca}\left(\mathrm{WO}_{4}\right)_{2}: 0.08 \mathrm{Dy}^{3+}$ phosphor emission was $0.032 \mathrm{~ms}$. With $\left[\mathrm{SiO}_{4}\right]^{4-}$ or $\left[\mathrm{PO}_{4}\right]^{3-}$ instead of $\left[\mathrm{WO}_{4}\right]^{2-}$, the fluorescence lifetime $\tau$ values of the $\mathrm{Li}_{2} \mathrm{Ca}_{2}\left(\mathrm{WO}_{4}\right)\left(\mathrm{SiO}_{4}\right): 0.08 \mathrm{Dy}^{3+}$ and $\mathrm{LiCa}_{2}\left(\mathrm{WO}_{4}\right)\left(\mathrm{PO}_{4}\right): 0.08 \mathrm{Dy}^{3+}$ were $0.024 \mathrm{~ms}$ and $0.049 \mathrm{~ms}$, respectively. The $\mathrm{LiCa}_{2}\left(\mathrm{WO}_{4}\right)\left(\mathrm{PO}_{4}\right): 0.08 \mathrm{Dy}^{3+}$ sample had the best fluorescence lifetime, which matched the previously described variations in the PL spectrum and thermal stability[31].

\subsection{CIE spectrum coordination}

Figure 7 shows CIE chromaticity diagrams of the $\mathrm{Li}_{2} \mathrm{Ca}\left(\mathrm{WO}_{4}\right)_{2}: 0.08 \mathrm{Dy}^{3+}$, $\mathrm{Li}_{2} \mathrm{Ca}_{2}\left(\mathrm{WO}_{4}\right)\left(\mathrm{SiO}_{4}\right): 0.08 \mathrm{Dy}^{3+}$, and $\mathrm{LiCa}_{2}\left(\mathrm{WO}_{4}\right)\left(\mathrm{PO}_{4}\right): 0.08 \mathrm{Dy}^{3+}$ samples and their corresponding photographs. The calculations demonstrated that the CIE chromaticity coordinates of the $\mathrm{Li}_{2} \mathrm{Ca}\left(\mathrm{WO}_{4}\right)_{2}: 0.08 \mathrm{Dy}^{3+}, \mathrm{Li}_{2} \mathrm{Ca}_{2}\left(\mathrm{WO}_{4}\right)\left(\mathrm{SiO}_{4}\right): 0.08 \mathrm{Dy}^{3+}$, and $\mathrm{LiCa}_{2}\left(\mathrm{WO}_{4}\right)\left(\mathrm{PO}_{4}\right): 0.08 \mathrm{Dy}^{3+}$ phosphors were 0.4053 and $0.4523,0.3892$ and 0.4215 , and 0.4124 and 0.4603 , respectively, corresponding to the yellow light area. In these systems, $\left[\mathrm{SiO}_{4}\right]^{4-}$ or $\left[\mathrm{PO}_{4}\right]^{3-}$ substituted $\left[\mathrm{WO}_{4}\right]^{2-}$, and the CIE chromaticity coordinates changed slightly, but the change was not large because the luminescent color of the 
fluorescent material was mainly determined by the type of doped rare earth ions[32]. Therefore, the yellow light-emitting phosphor that was effectively excited by the nearultraviolet light chip was obtained by doping the aforementioned matrix material with $\mathrm{Dy}^{3+}$ ions, and the three kinds of fluorescent materials prepared have potential application materials as yellow phosphors for white LEDs.

\section{Conclusion}

The pure phases of the $\mathrm{Dy}^{3+}$-doped scheelite structure $\mathrm{Li}_{2} \mathrm{Ca}\left(\mathrm{WO}_{4}\right)_{2}: 0.08 \mathrm{Dy}^{3+}$, $\mathrm{Li}_{2} \mathrm{Ca}_{2}\left(\mathrm{WO}_{4}\right)\left(\mathrm{SiO}_{4}\right): 0.08 \mathrm{Dy}^{3+}$, and $\mathrm{LiCa}_{2}\left(\mathrm{WO}_{4}\right)\left(\mathrm{PO}_{4}\right): 0.08 \mathrm{Dy}^{3+}$ phosphors were successfully prepared using a high-temperature solid-phase reaction. The prepared phosphors had a wide excitation band in the $320-430 \mathrm{~nm}$ band, which could be matched with commercial $n$-UV LED chips. These phosphors mainly emit yellow light peaks at $576 \mathrm{~nm}$, and the optimum doping concentration was determined to be $0.08 \% \mathrm{~mol}$. When $\left[\mathrm{SiO}_{4}\right]^{4-} /\left[\mathrm{PO}_{4}\right]^{3-}$ substituted $\left[\mathrm{WO}_{4}\right]^{2-}$, the luminescent properties, thermal stability, and lifetime decay curves of the phosphors were modified. The results showed that the as-prepared fluorescent materials had excellent thermal stability and can be used as potential $w$-LED luminescent materials.

\section{Acknowledgments}

This study was supported by the National Natural Science Foundation of China (grant nos. 41831288 and 51672257), the Fundamental Research Funds for the Central Universities (grant nos. 2652018305 and 2652017335). 


\section{Reference}

[1] Fu Z, Wang K, Zou B. Recent advances in organic pressure-responsive luminescent materials. Chin Chem Lett 2019, 30: 1883-1894.

[2] Yingsen Y U, Liu X, Zhou Z . Luminescence enhancement of Ca/VtoO4:Eu (3+) phosphor by charge compensation using microwave sintering method. $J$ Adv Ceram 2015, 4(4): 318-325.

[3] Wang X, Li X, Shen R, et al. Optical transition and luminescence properties of $\mathrm{Sm}^{3+}$ - doped $\mathrm{YNbO}_{4}$ powder phosphor. J Am Ceram Soc 2020,103(2):1034-1045.

[4] Wei Y, Su C, Zhang H, et al. Color-tunable up-conversion emission from $\mathrm{Yb}^{3+} / \mathrm{Er}^{3+} / \mathrm{Tm}^{3+} / \mathrm{Ho}^{3+}$ codoped $\mathrm{KY}\left(\mathrm{MoO}_{4}\right)_{2}$ microcrystals based on energy transfer. Ceram Int 2016, 42: 4642-4647.

[5] Jin C, Zhang J. Upconversion luminescence of $\mathrm{Ca}_{2} \mathrm{Gd}_{8}\left(\mathrm{SiO}_{4}\right)_{6} \mathrm{O}_{2}: \mathrm{Yb}^{3+}-\mathrm{Tm}^{3+}-$ $\mathrm{Tb}^{3+} / \mathrm{Eu}^{3+}$ phosphors for optical temperature sensing. Opt Laser Technol 2019, 115: 487-492.

[6] Que M, Ci Z, Wang Y, et al. Synthesis and luminescent properties of $\mathrm{Ca}_{2} \mathrm{La}_{8}\left(\mathrm{GeO}_{4}\right)_{6} \mathrm{O}_{2}: \mathrm{RE}^{3+}\left(\mathrm{RE}^{3+}=\mathrm{Eu}^{3+}, \mathrm{Tb}^{3+}, \mathrm{Dy}^{3+}, \mathrm{Sm}^{3+}, \mathrm{Tm}^{3+}\right)$ phosphors. $J$ Lumines 2013, 144: 64-68.

[7] Ferhi M, Toumi S, Horchani-Naifer K, et al. Single phase $\mathrm{GdPO}_{4}$ : $\mathrm{Dy}^{3+}$ microspheres blue, yellow and white light emitting phosphor. J Alloy Compd 2017, 714:144-153.

[8] Wang GQ, Gong XH. Chen YJ, et al. Synthesis and photoluminescence properties of near-UV pumped yellow-emitting $\mathrm{Li}_{3} \mathrm{Ba}_{2} \mathrm{La}_{3}\left(\mathrm{WO}_{4}\right)_{8}: \mathrm{Dy}^{3+}$ phosphors. Opt Mater 2014, 36:1255-1259.

[9] Martínez-Martínez R, Lira AC, Speghini A, et al. Blue-yellow photoluminescence from $\mathrm{Ce}^{3+} \rightarrow \mathrm{Dy}^{3+}$ energy transfer in $\mathrm{HfO}_{2}: \mathrm{Ce}^{3+}: \mathrm{Dy}^{3+}$ films deposited by ultrasonic spray pyrolysis. J Alloy Compd 2011, 509:3160-3165.

[10] Sabalisck NP, Lahoz F, González-Silgo MC, et al. Control of the luminescent properties of $\mathrm{Eu}_{2-\mathrm{x}} \mathrm{Dy}_{\mathrm{x}}\left(\mathrm{WO}_{4}\right)_{3}$ solid solutions for scintillator applications. J Alloy Compd 2017, 726: 796-802. 
[11] Ivanov YF, Denisova Y, Devyatkov VN, et al. Modification of the structure and phase composition of structural steel by a microsecond e-beam. High Temp Mater Process 2015, 17:236-239 .

[12] Xiang QC, Liu QL, Qin SQ, et al. Relationship of 5d-level energies of $\mathrm{Ce}^{3+}$ with the structure and composition of nitride hosts. J Lumines 2015,166:106-110.

[13] Guo W, Tian Y, Huang P, et al. Color tunable luminescence in novel $\mathrm{Li}_{3} \mathrm{Ba}_{2} \mathrm{Y}_{3}\left(\mathrm{WO}_{4}\right)_{8}: \mathrm{Tb}^{3+}, \mathrm{Eu}^{3+}$ phosphor for white LEDs. Ceram Int 2016, 42: $5427-$ 5432.

[14] Kasprowicz D, Brik MG, Majchrowski A, et al. Spectroscopic properties of $\mathrm{KGd}\left(\mathrm{WO}_{4}\right)_{2}$ single crystals doped with $\mathrm{Er}^{3+}, \mathrm{Ho}^{3+}, \mathrm{Tm}^{3+}$ and $\mathrm{Yb}^{3+}$ ions: Luminescence and micro-Raman investigations. J Alloy Compd 2013, 577: 687692.

[15] Yu X, Gao M, Li J, et al. Near infrared to visible upconversion emission in $\mathrm{Er}^{3+} / \mathrm{Yb}^{3+}$ co-doped $\mathrm{NaGd}\left(\mathrm{WO}_{4}\right)_{2}$ nanoparticles obtained by hydrothermal method. $J$ Lumines 2014, 154:111-115.

[16] Wang L, Guo W, Tian Y, et al. High luminescent brightness and thermal stability of red emitting $\mathrm{Li}_{3} \mathrm{Ba}_{2} \mathrm{Y}_{3}\left(\mathrm{WO}_{4}\right)_{8}: \mathrm{Eu}^{3+}$ phosphor. Ceram Int 2016, 42:13648-13653.

[17] Kasprowicz D, Głuchowski P, Brik MG, et al. Visible and near-infrared upconversion luminescence of $\mathrm{KGd}\left(\mathrm{WO}_{4}\right)_{2}$ micro-crystals doped with $\mathrm{Er}^{3+}, \mathrm{Tm}^{3+}$, $\mathrm{Ho}^{3+}$ and $\mathrm{Yb}^{3+}$ ions. J Alloy Compd 2016, 684:271-281.

[18] Bin J, Liu H, Mei L, et al. Multi-color luminescence evolution and efficient energy transfer of scheelite-type $\mathrm{LiCaGd}\left(\mathrm{WO}_{4}\right)_{3}: \mathrm{Ln}^{3+}(\mathrm{Ln}=\mathrm{Eu}$, Dy, Tb) phosphors. Ceram Int 2019, 45:1837-1845.

[19] Lim H, Lim J, Jang S, et al. Emissions of $\mathrm{Er}^{3+}$ and $\mathrm{Yb}^{3+}$ co-doped $\mathrm{SrZrO}_{3}$ nanocrystals under near-infrared and near-ultraviolet excitations. J Adv Ceram 2020, 9:413-423.

[20] Zhang Y, Mei L, Liu H, et al. Dysprosium doped novel apatite-type white-emitting phosphor $\mathrm{Ca} 9 \mathrm{La}\left(\mathrm{PO}_{4}\right)_{5}\left(\mathrm{GeO}_{4}\right) \mathrm{F}_{2}$ with satisfactory thermal properties for n-UVwLEDs. Dyes Pigment 2017, 139:180-186. 
[21] Chartier A, Meis C, Gale JD, Computational study of Cs immobilization in the apatites $\mathrm{Ca}_{10}\left(\mathrm{PO}_{4}\right)_{6} \mathrm{~F}_{2}, \mathrm{Ca}_{4} \mathrm{La}_{6}\left(\mathrm{SiO}_{4}\right)_{6} \mathrm{~F}_{2}$ and $\mathrm{Ca}_{2} \mathrm{La}_{8}\left(\mathrm{SiO}_{4}\right)_{6} \mathrm{O}_{2}$. Phys Rev $B$ 2001, 64:085110-085119.

[22] Liu H, Mei L, Liao L, et al. Strategy for realizing ratiometric optical thermometry via efficient $\mathrm{Tb}^{3+}-\mathrm{Mn}^{2+}$ energy transfer in novel apatite-type phosphor $\mathrm{Ca}_{9} \mathrm{~Tb}\left(\mathrm{PO}_{4}\right)_{5}\left(\mathrm{SiO}_{4}\right) \mathrm{F}_{2}$. J Alloy Compd 2019, 770:1237-1243.

[23] Liu H, Liao L, Guo Q, et al. $\mathrm{Ca} 9 \mathrm{La}\left(\mathrm{PO}_{4}\right)_{5}\left(\mathrm{SiO}_{4}\right) \mathrm{Cl}_{2}$ : $\mathrm{Dy}^{3+}$ : A white-emitting apatitetype phosphor pumped for n-UV w-LEDs. J Lumines 2017, 181:407-410.

[24] Kershi R M, Ali F M, and Sayed M A. Influence of rare earth ion substitutions on the structural, optical, transport, dielectric, and magnetic properties of superparamagnetic iron oxide nanoparticles. $J$ Adv Ceram 2018, 7(3):218-228.

[25] Yuan N, Liu DY, Yu XC, et al. A biological nano-thermometer based on ratiometric luminescent $\mathrm{Er}^{3+} / \mathrm{Yb}^{3+}$-codoped $\mathrm{NaGd}\left(\mathrm{WO}_{4}\right)_{2}$ nanocrystals. Mater Lett 2018, 218:337-340.

[26] Yue G, Moon BK, Choi BC, et al. Multi-wavelength excited white-emitting $\mathrm{K}_{2} \mathrm{Gd}_{(1-\mathrm{x})}\left(\mathrm{PO}_{4}\right)\left(\mathrm{WO}_{4}\right): \mathrm{xDy}^{3+}$ phosphors with satisfactory thermal properties for UV-LEDs. RSC Adv 2017, 7:23083-23092.

[27] Liu H, Liao L, Guo Q, et al. Synthesis and Photoluminescence Properties of Dy ${ }^{3+}$ Doped White-Emitting Phosphor $\mathrm{Sr}_{9} \mathrm{La}\left(\mathrm{PO}_{4}\right)_{3}\left(\mathrm{SiO}_{4}\right) \mathrm{Cl}_{2} \quad$ :Dy $^{3+}$. Nanosci Nanotechnol Lett 2017, 9:252-255.

[28] Wu X, Liang Y, Liu S, et al. Investigation of the luminescence properties and thermal stability of dysprosium, terbium, and europium ions singly- and co-doped strontium yttrium borate phosphors. Spectr Lett 2017, 50:48-54.

[29] Lima NA, Alencar LDS, Máximo Siu-Li, et al. $\mathrm{NiWO}_{4}$ powders prepared via polymeric precursor method for application as ceramic luminescent pigments. $J$ Adv Ceram 2020, 9(1):55-63.

[30] Liu N, Si JY, Cai GM, et al. Crystal structure, luminescence properties and energy transfer of $\mathrm{Eu}^{3+} / \mathrm{Dy}^{3+}$ doped $\mathrm{GdNbTiO}_{6}$ broad band excited phosphors. RSC Adv 2016, 6:50797-50807. 
[31] Wu Y, Yang F, Yan F. Warm-white light performance of $\mathrm{Dy}^{3+}, \mathrm{Eu}^{3+}: \mathrm{NaLa}\left(\mathrm{WO}_{4}\right)_{2}$ phosphors excited with a 450-nm LED. J Am Ceram Soc 2019, 102(12).7347-7354

[32] Zhou Z, Yu Y, Liu X, et al. Luminescence enhancement of $\mathrm{CaMoO}_{4}: \mathrm{Eu}^{3+}$

phosphor by charge compensation using microwave sintering method. $J A d v$

Ceram 2015, 4:318-325 


\section{Table captions}

Table 1 Chemical analysis of fractions of $\mathrm{Li}_{2} \mathrm{Ca}_{2}\left(\mathrm{WO}_{4}\right)\left(\mathrm{SiO}_{4}\right)(\mathrm{O}, \mathrm{P}, \mathrm{Ca}, \mathrm{W})$.

Table 2 Chemical analysis of fractions of LiCa2(WO4)(PO4) (O, Si, Ca, W).

Table 1 Chemical analysis of fractions of $\mathrm{Li}_{2} \mathrm{Ca}_{2}\left(\mathrm{WO}_{4}\right)\left(\mathrm{SiO}_{4}\right)(\mathrm{O}, \mathrm{P}, \mathrm{Ca}, \mathrm{W})$.

\begin{tabular}{cc}
\hline Chemical composition & Weight $(\%)$ \\
\hline $\mathrm{O}$ & 29.79 \\
$\mathrm{P}$ & 7.21 \\
$\mathrm{Ca}$ & 18.62 \\
$\mathrm{~W}$ & 42.77 \\
\hline
\end{tabular}

Table 2 Chemical analysis of fractions of $\mathrm{LiCa} 2(\mathrm{WO} 4)(\mathrm{PO} 4)(\mathrm{O}, \mathrm{Si}, \mathrm{Ca}, \mathrm{W})$

\begin{tabular}{cc}
\hline Chemical composition & Weight $(\%)$ \\
\hline $\mathrm{O}$ & 40.29 \\
$\mathrm{Ca}$ & 6.31 \\
$\mathrm{~W}$ & 16.88 \\
\hline
\end{tabular}




\section{Figure captions}

Figure. 1. XRD pattern of $\mathrm{Li}_{2} \mathrm{Ca}\left(\mathrm{WO}_{4}\right)_{2}: \mathrm{xDy}^{3+}, \mathrm{Li}_{2} \mathrm{Ca}_{2}\left(\mathrm{WO}_{4}\right)\left(\mathrm{SiO}_{4}\right): \mathrm{yDy}^{3+}$, $\mathrm{LiCa}_{2}\left(\mathrm{WO}_{4}\right)\left(\mathrm{PO}_{4}\right): \mathrm{zDy}^{3+}$ samples with the PDF\#41-1431 $\left(\mathrm{CaWO}_{4}\right)$ as a reference.

Figure. 2. (a) EDS spectrum, (b) SEM image, (c) elemental mappings of the $\mathrm{Li}_{2} \mathrm{Ca}_{2} \mathrm{WO}_{4} \mathrm{SiO}_{4}$ phosphor; (d) EDS spectrum , (e) SEM image, (f) elemental mappings of the $\mathrm{Li}_{2} \mathrm{Ca}_{2} \mathrm{WO}_{4} \mathrm{SiO}_{4}$ phosphor.

Figure. 3. Excitation and emission spectra of spectra of (a) $\mathrm{Li}_{2} \mathrm{Ca}_{2}\left(\mathrm{WO}_{4}\right)\left(\mathrm{SiO}_{4}\right): \mathrm{yDy}^{3+}$,

(b) $\mathrm{LiCa}_{2}\left(\mathrm{WO}_{4}\right)\left(\mathrm{PO}_{4}\right): \mathrm{zDy}^{3+}$ samples, (c) and (d) inset shows the corresponding dependence of PL intensity of $\mathrm{Dy}^{3+}$ transition.

Figure. 4. PL spectra of (a) $\mathrm{Li}_{2} \mathrm{Ca}\left(\mathrm{WO}_{4}\right)_{2}: 0.08 \mathrm{Dy}^{3+}$, (b) $\mathrm{Li}_{2} \mathrm{Ca}_{2}\left(\mathrm{WO}_{4}\right)\left(\mathrm{SiO}_{4}\right): 0.08 \mathrm{Dy}^{3+}$ and (c) $\mathrm{LiCa}_{2}\left(\mathrm{WO}_{4}\right)\left(\mathrm{PO}_{4}\right): 0.08 \mathrm{Dy}^{3+}$ samples and (b) Inset shows the corresponding dependence of PL intensity of $\mathrm{Dy}^{3+}$ transition.

Figure. 5. The PL spectra $(\lambda e x=353 \mathrm{~nm})$ of (a) $\mathrm{Li}_{2} \mathrm{Ca}\left(\mathrm{WO}_{4}\right)_{2}: 0.08 \mathrm{Dy}^{3+}$, (b) $\mathrm{Li}_{2} \mathrm{Ca}_{2}\left(\mathrm{WO}_{4}\right)\left(\mathrm{SiO}_{4}\right): 0.08 \mathrm{Dy}^{3+}$ and $(\mathrm{c}) \mathrm{LiCa}_{2}\left(\mathrm{WO}_{4}\right)\left(\mathrm{PO}_{4}\right): 0.08 \mathrm{Dy}^{3+}$ samples under different temperatures in the range of $30-300{ }^{\circ} \mathrm{C}$, every inset shows the corresponding dependence of PL intensity of $\mathrm{Dy}^{3+}$ transition.

Figure. 6. Decay curves and lifetimes $(\tau)$ of (a) $\mathrm{Li}_{2} \mathrm{Ca}\left(\mathrm{WO}_{4}\right)_{2}: 0.08 \mathrm{Dy}^{3+}$, (b) 
$\mathrm{Li}_{2} \mathrm{Ca}_{2}\left(\mathrm{WO}_{4}\right)\left(\mathrm{SiO}_{4}\right): 0.08 \mathrm{Dy}^{3+}$ and (c) $\mathrm{LiCa}_{2}\left(\mathrm{WO}_{4}\right)\left(\mathrm{PO}_{4}\right): 0.08 \mathrm{Dy}^{3+}$ samples $\left(\lambda_{\mathrm{em}}=576 \mathrm{~nm}\right)$ after the pulsed excitation $\left(\lambda_{\mathrm{ex}}=353 \mathrm{~nm}\right)$ at RT.

Figure. 7. CIE color coordinates for the $\mathrm{Li}_{2} \mathrm{Ca}\left(\mathrm{WO}_{4}\right)_{2}: 0.08 \mathrm{Dy}^{3+}$ (orange star), $\mathrm{Li}_{2} \mathrm{Ca}_{2}\left(\mathrm{WO}_{4}\right)\left(\mathrm{SiO}_{4}\right): 0.08 \mathrm{Dy}^{3+}$ (red star) and $\mathrm{LiCa}_{2}\left(\mathrm{WO}_{4}\right)\left(\mathrm{PO}_{4}\right): 0.08 \mathrm{Dy}^{3+}$ (purple star)at RT. The results are calculated using the emission spectra under $353 \mathrm{~nm}$ excitation. 


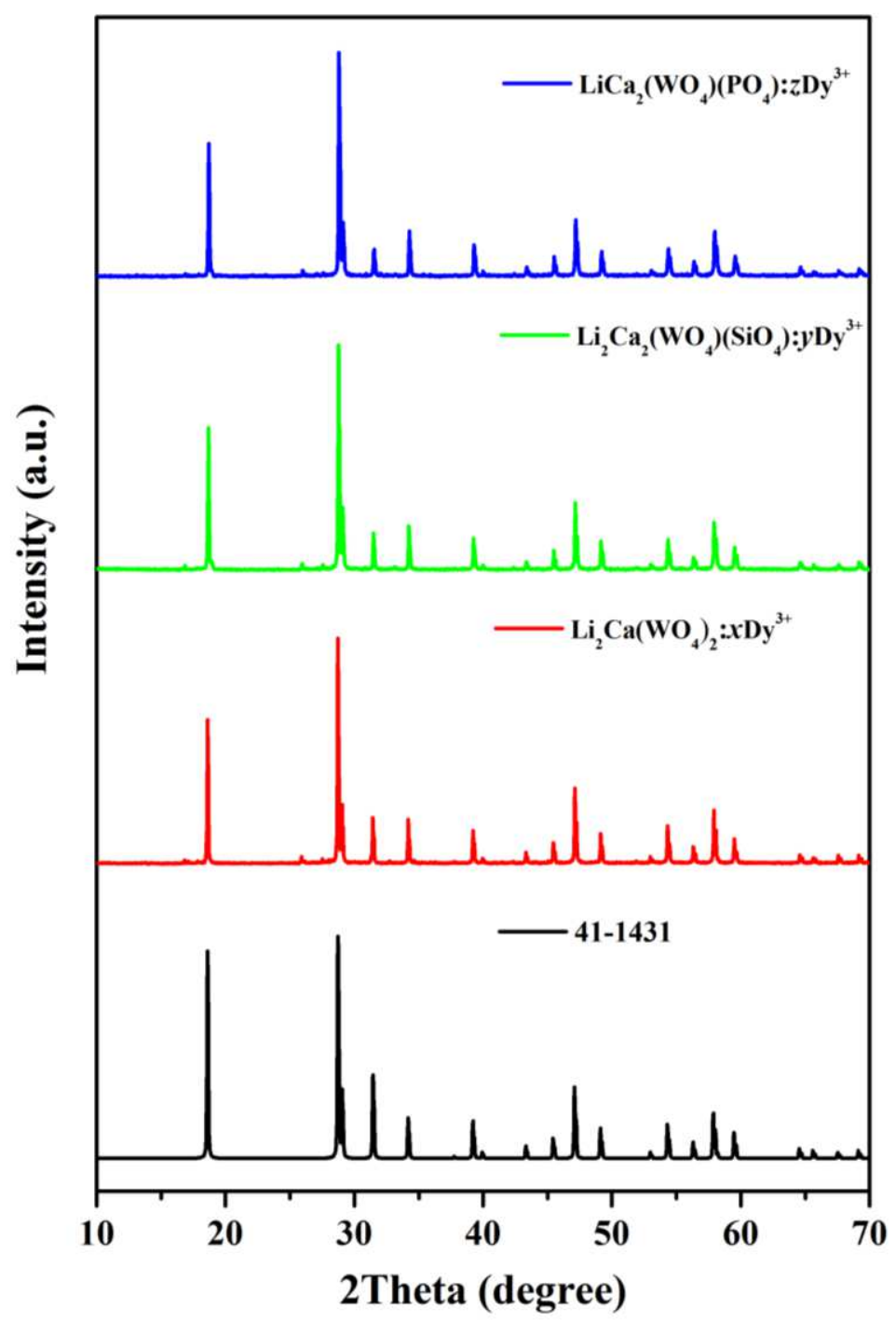

Figure. 1. XRD pattern of $\mathrm{Li}_{2} \mathrm{Ca}\left(\mathrm{WO}_{4}\right)_{2}: \mathrm{xDy}^{3+}, \mathrm{Li}_{2} \mathrm{Ca}_{2}\left(\mathrm{WO}_{4}\right)\left(\mathrm{SiO}_{4}\right): \mathrm{yDy}^{3+}$, $\mathrm{LiCa}_{2}\left(\mathrm{WO}_{4}\right)\left(\mathrm{PO}_{4}\right): \mathrm{zDy}^{3+}$ samples with the PDF\#41-1431 $\left(\mathrm{CaWO}_{4}\right)$ as a reference. 

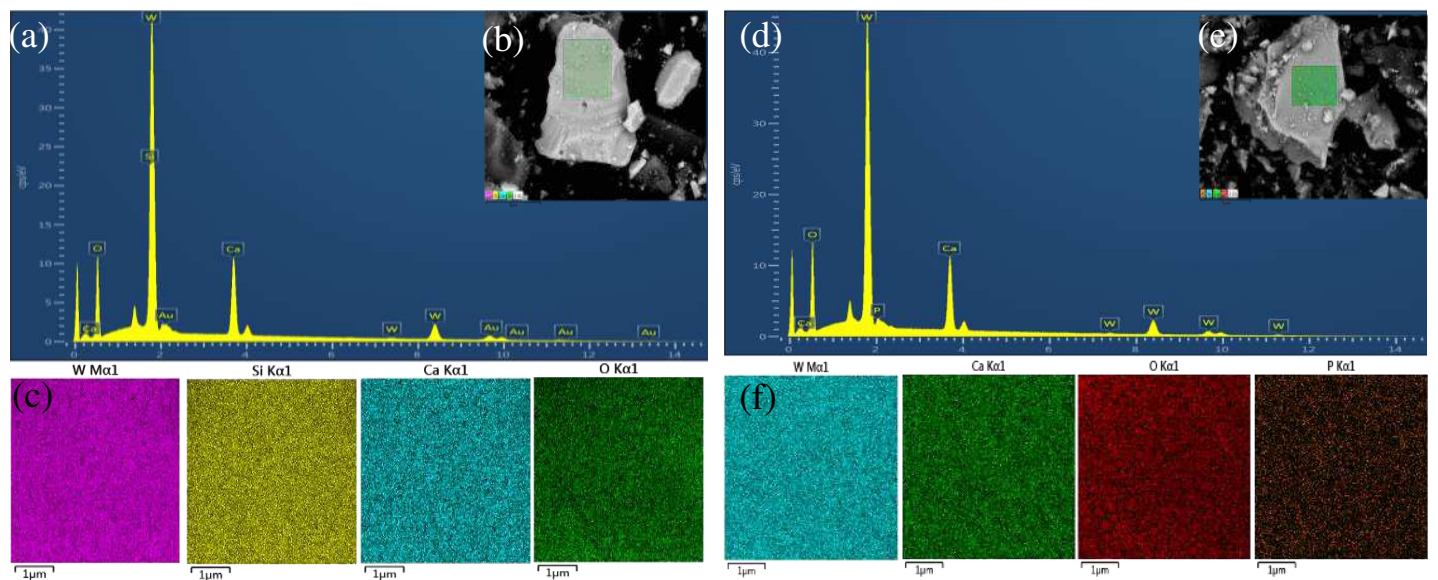

Figure. 2. (a) EDS spectrum, (b) SEM image, (c) elemental mappings of the

$\mathrm{Li}_{2} \mathrm{Ca}_{2} \mathrm{WO}_{4} \mathrm{SiO}_{4}$ phosphor; (d) EDS spectrum, (e) SEM image, (f) elemental mappings of the $\mathrm{Li}_{2} \mathrm{Ca}_{2} \mathrm{WO}_{4} \mathrm{SiO}_{4}$ phosphor.
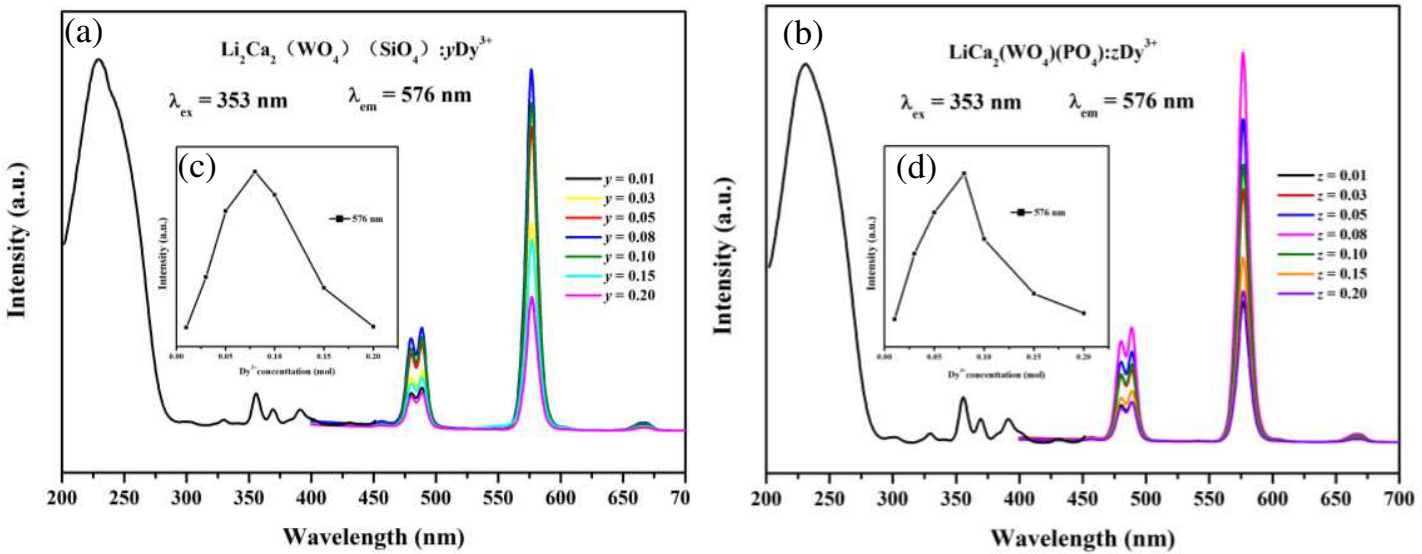

Figure 3 Excitation and emission spectra of spectra of (a) $\mathrm{Li}_{2} \mathrm{Ca}_{2}\left(\mathrm{WO}_{4}\right)\left(\mathrm{SiO}_{4}\right): \mathrm{yDy}^{3+}$, (b) $\mathrm{LiCa}_{2}\left(\mathrm{WO}_{4}\right)\left(\mathrm{PO}_{4}\right): \mathrm{zDy}^{3+}$ samples, (c) and (d) inset shows the corresponding dependence of PL intensity of $\mathrm{Dy}^{3+}$ transition. 


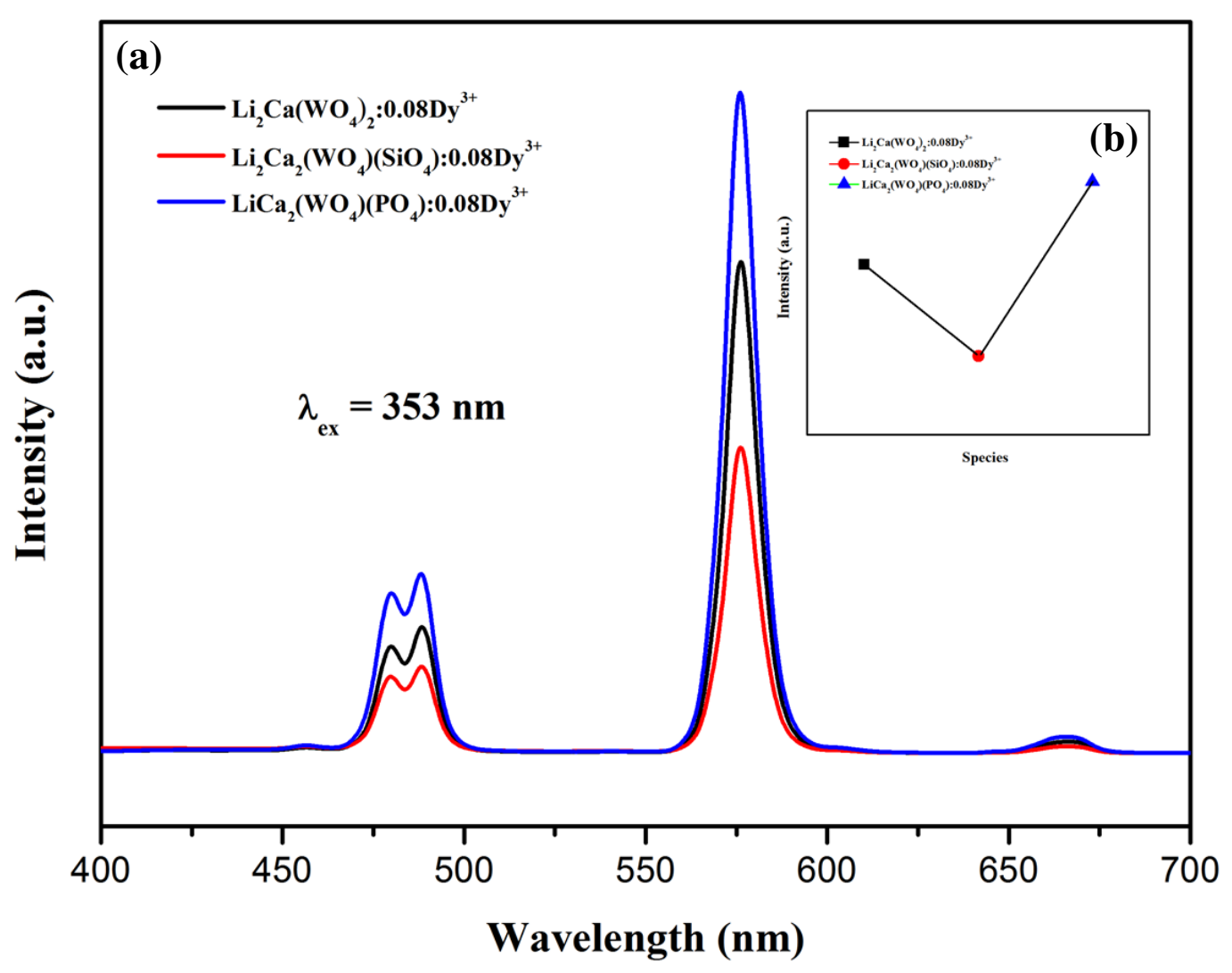

Figure. 4. $\mathrm{PL}$ spectra of $\mathrm{Li}_{2} \mathrm{Ca}\left(\mathrm{WO}_{4}\right)_{2}: 0.08 \mathrm{Dy}^{3+}, \mathrm{Li}_{2} \mathrm{Ca}_{2}\left(\mathrm{WO}_{4}\right)\left(\mathrm{SiO}_{4}\right): 0.08 \mathrm{Dy}^{3+}$ and $\mathrm{LiCa}_{2}\left(\mathrm{WO}_{4}\right)\left(\mathrm{PO}_{4}\right): 0.08 \mathrm{Dy}^{3+}$ samples and (b) Inset shows the corresponding dependence of PL intensity of $\mathrm{Dy}^{3+}$ transition. 

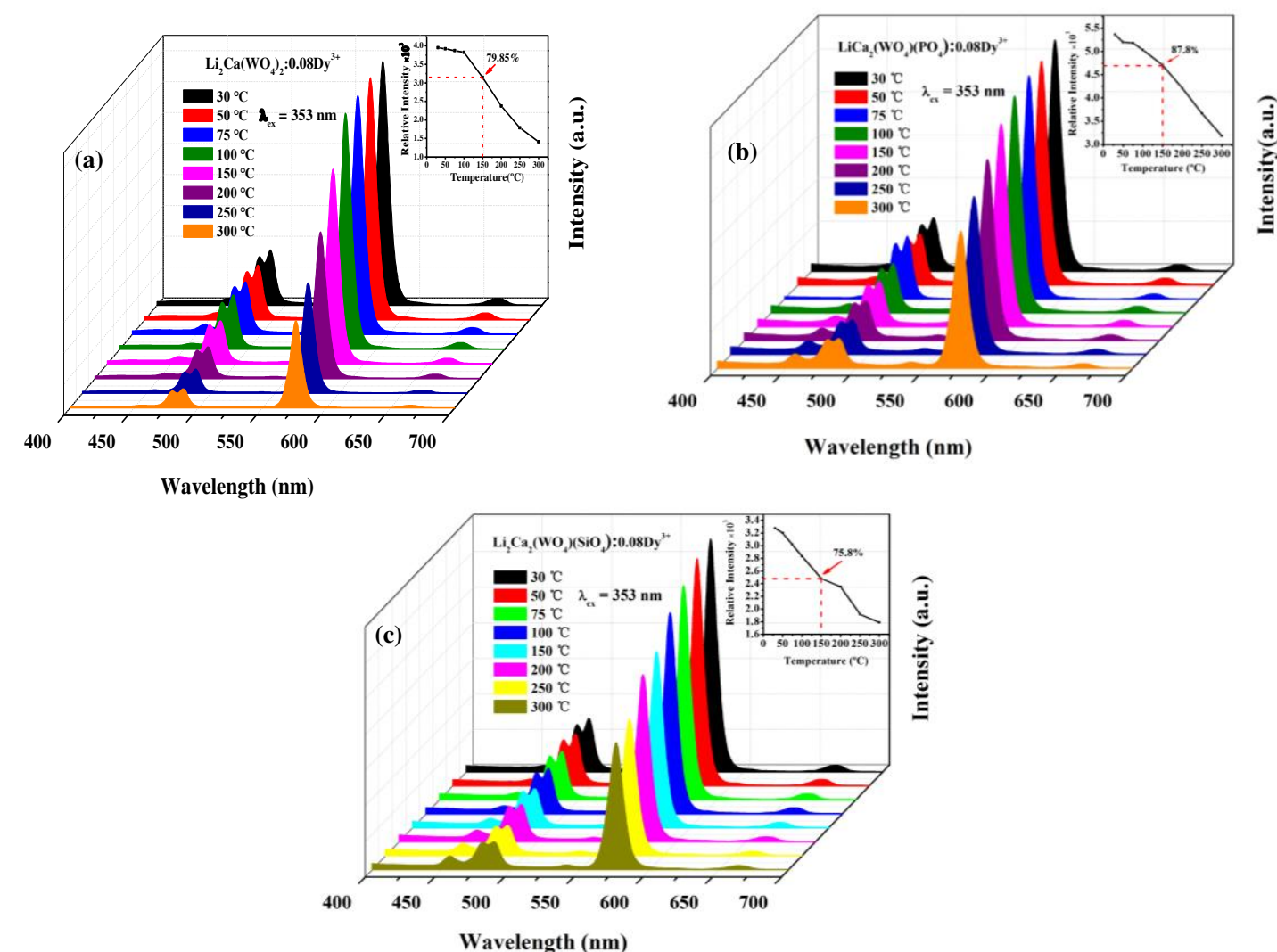

Figure. 5. The PL spectra $(\lambda \mathrm{ex}=353 \mathrm{~nm})$ of (a) $\mathrm{Li}_{2} \mathrm{Ca}\left(\mathrm{WO}_{4}\right)_{2}: 0.08 \mathrm{Dy}^{3+}$, (b) $\mathrm{Li}_{2} \mathrm{Ca}_{2}\left(\mathrm{WO}_{4}\right)\left(\mathrm{SiO}_{4}\right): 0.08 \mathrm{Dy}^{3+}$ and $(\mathrm{c}) \mathrm{LiCa}_{2}\left(\mathrm{WO}_{4}\right)\left(\mathrm{PO}_{4}\right): 0.08 \mathrm{Dy}^{3+}$ samples under different temperatures in the range of $30-300{ }^{\circ} \mathrm{C}$, every inset shows the corresponding dependence of PL intensity of $\mathrm{Dy}^{3+}$ transition. 


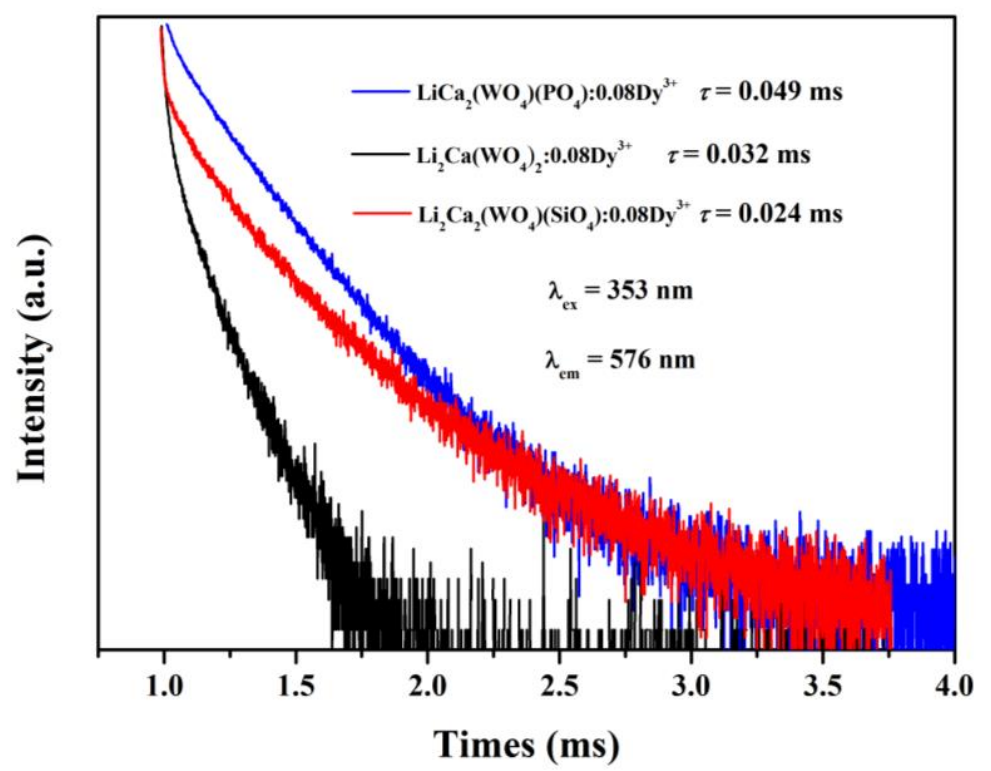

Figure. 6. Decay curves and lifetimes $(\tau)$ of $\mathrm{Li}_{2} \mathrm{Ca}\left(\mathrm{WO}_{4}\right)_{2}: 0.08 \mathrm{Dy}^{3+}$, $\mathrm{Li}_{2} \mathrm{Ca}_{2}\left(\mathrm{WO}_{4}\right)\left(\mathrm{SiO}_{4}\right): 0.08 \mathrm{Dy}^{3+}$ and $\mathrm{LiCa}_{2}\left(\mathrm{WO}_{4}\right)\left(\mathrm{PO}_{4}\right): 0.08 \mathrm{Dy}^{3+}$ samples $\left(\lambda_{\mathrm{em}}=576 \mathrm{~nm}\right)$ after the pulsed excitation $\left(\lambda_{\mathrm{ex}}=353 \mathrm{~nm}\right)$ at $\mathrm{RT}$.

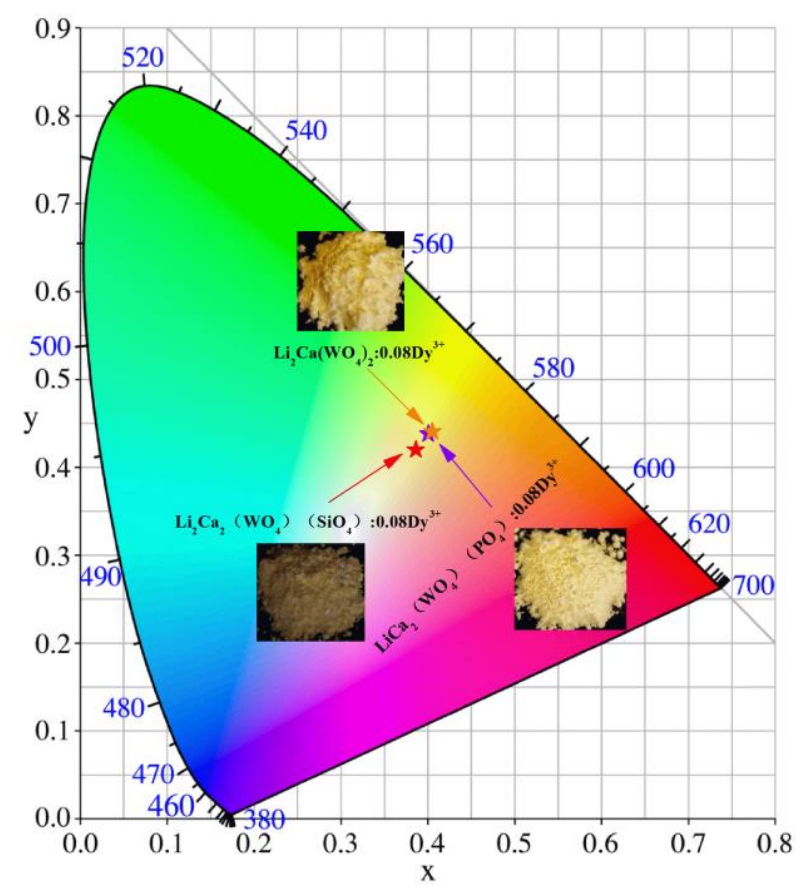

Figure. 7. CIE color coordinates for the $\mathrm{Li}_{2} \mathrm{Ca}\left(\mathrm{WO}_{4}\right)_{2}: 0.08 \mathrm{Dy}^{3+}$ (orange star), $\mathrm{Li}_{2} \mathrm{Ca}_{2}\left(\mathrm{WO}_{4}\right)\left(\mathrm{SiO}_{4}\right): 0.08 \mathrm{Dy}^{3+}$ (red star) and $\mathrm{LiCa}_{2}\left(\mathrm{WO}_{4}\right)\left(\mathrm{PO}_{4}\right): 0.08 \mathrm{Dy}^{3+}$ (purple star)at RT. The results are calculated using the emission spectra under $353 \mathrm{~nm}$ excitation. 
Figures

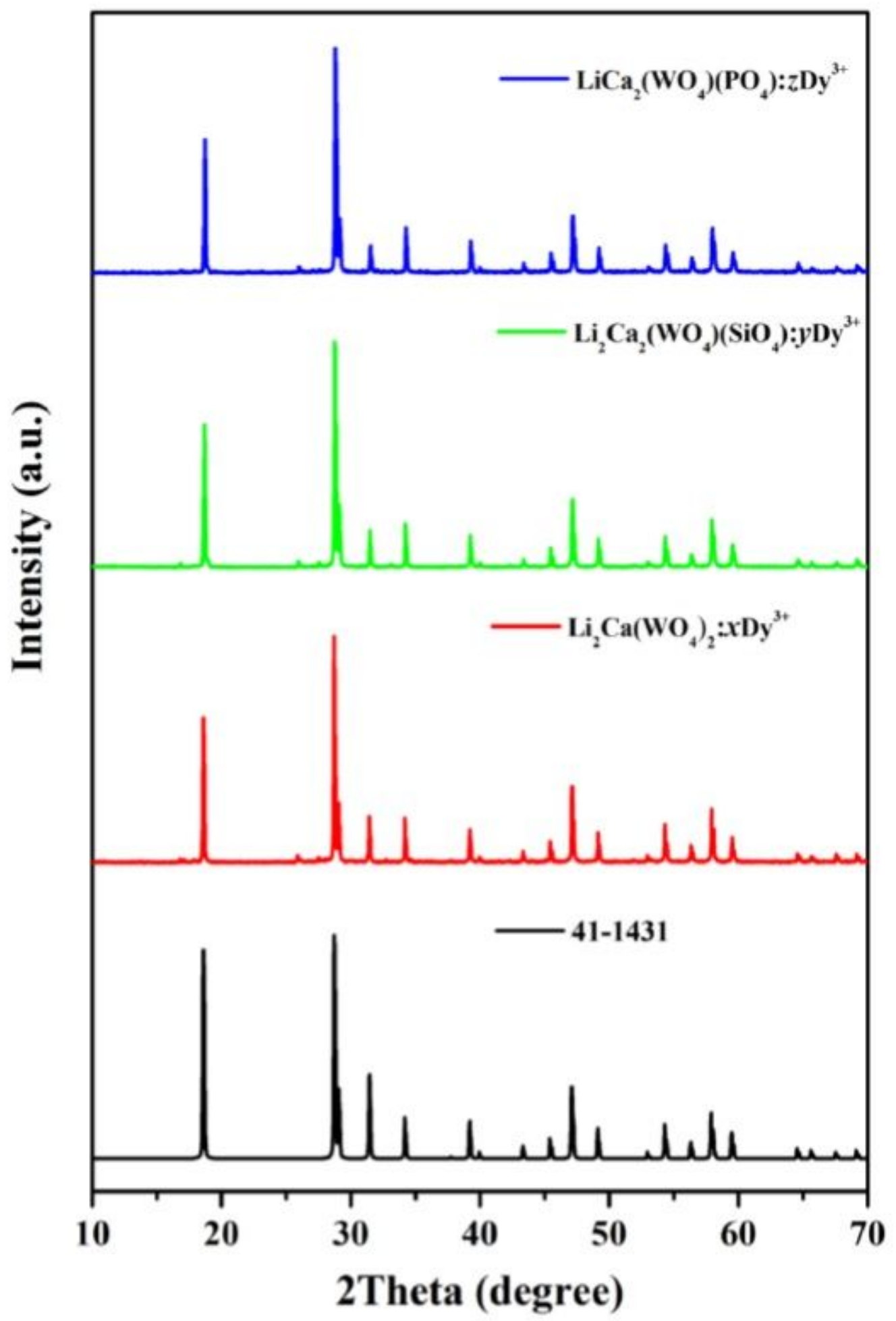

Figure 1

XRD pattern of Li2Ca(WO4)2:xDy3+, Li2Ca2(WO4)(SiO4):yDy3+, LiCa2(WO4)(PO4):zDy3+ samples with the PDF\#41-1431 (CaWO4) as a reference. 

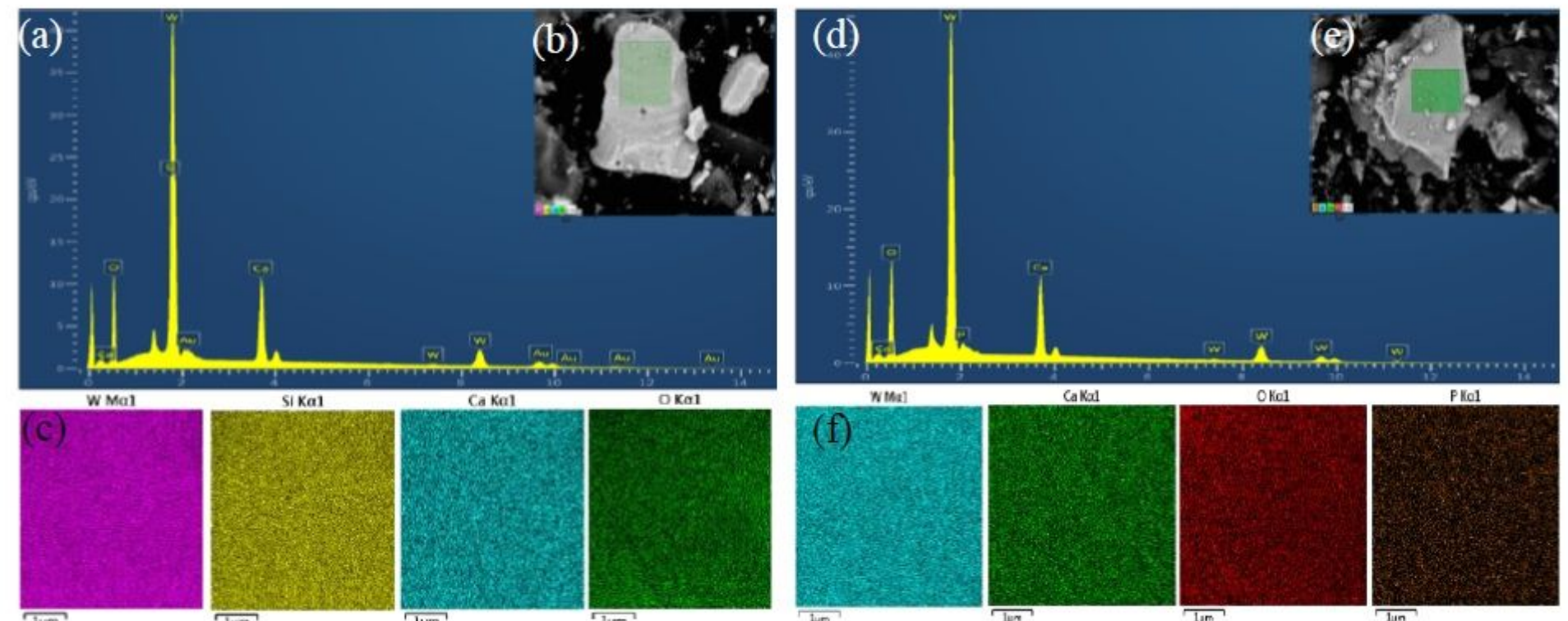

\section{Figure 2}

(a) EDS spectrum, (b) SEM image, (c) elemental mappings of the Li2Ca2WO4SiO4 phosphor; (d) EDS spectrum , (e) SEM image, (f) elemental mappings of the Li2Ca2WO4SiO4 phosphor.
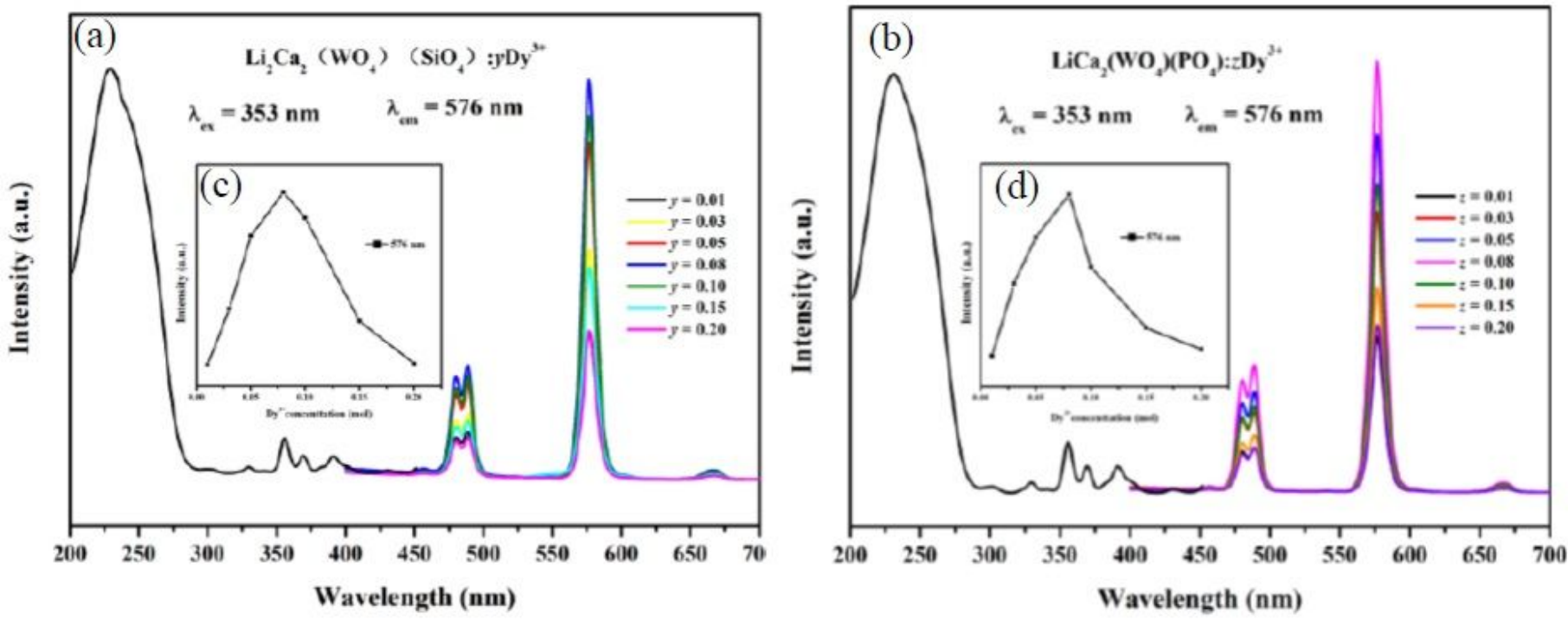

Figure 3

Excitation and emission spectra of spectra of (a) Li2Ca2(WO4)(SiO4):yDy3+, (b) LiCa2(WO4) (P04):zDy3+ samples, (c) and (d) inset shows the corresponding dependence of PL intensity of Dy3+ transition. 


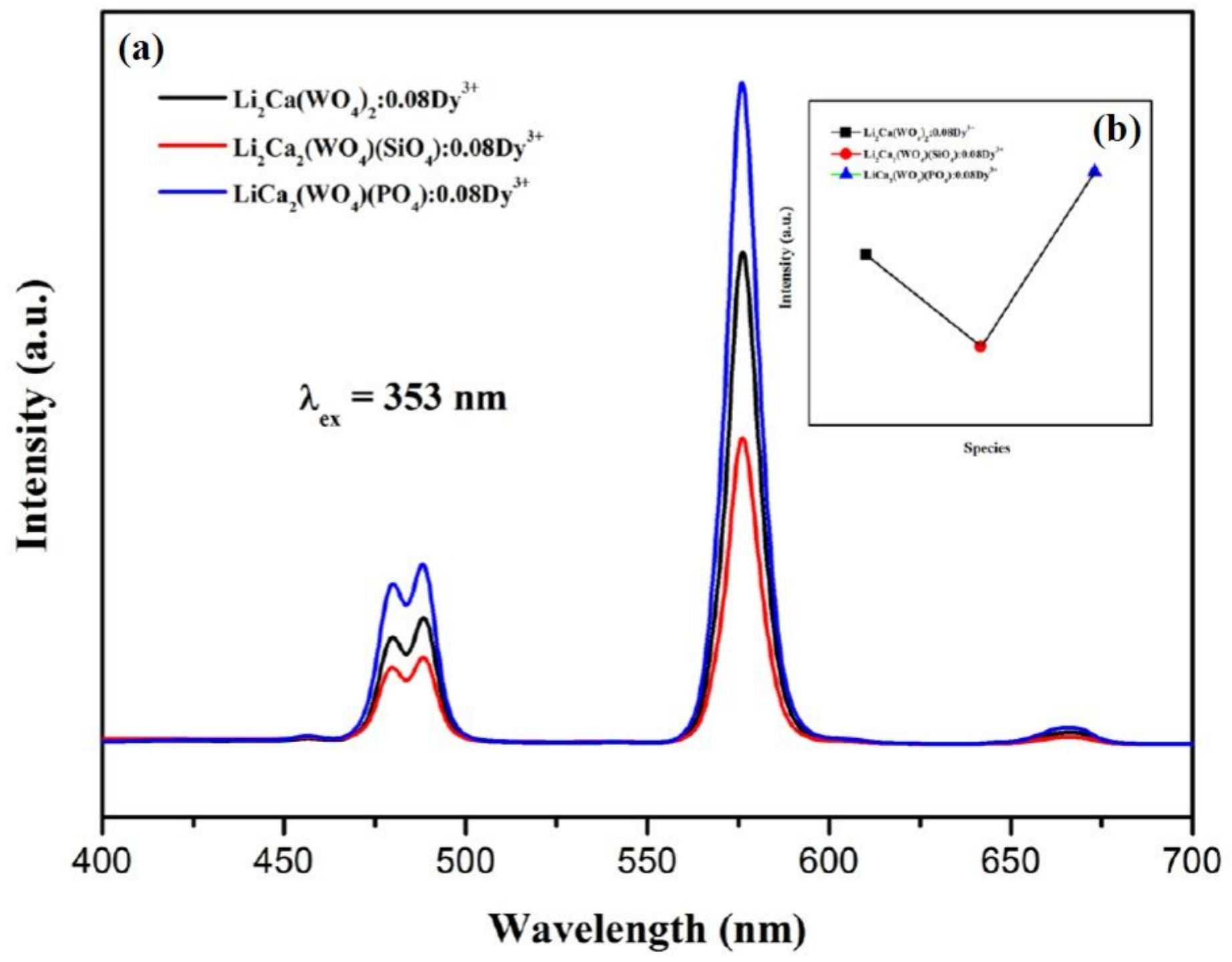

Figure 4

PL spectra of (a) Li2Ca(WO4)2:0.08Dy3+, (b) Li2Ca2(WO4)(SiO4): 0.08Dy3+ and (c) LiCa2(WO4)(PO4): 0.08Dy3+ samples and (b) Inset shows the corresponding dependence of PL intensity of Dy3+ transition. 

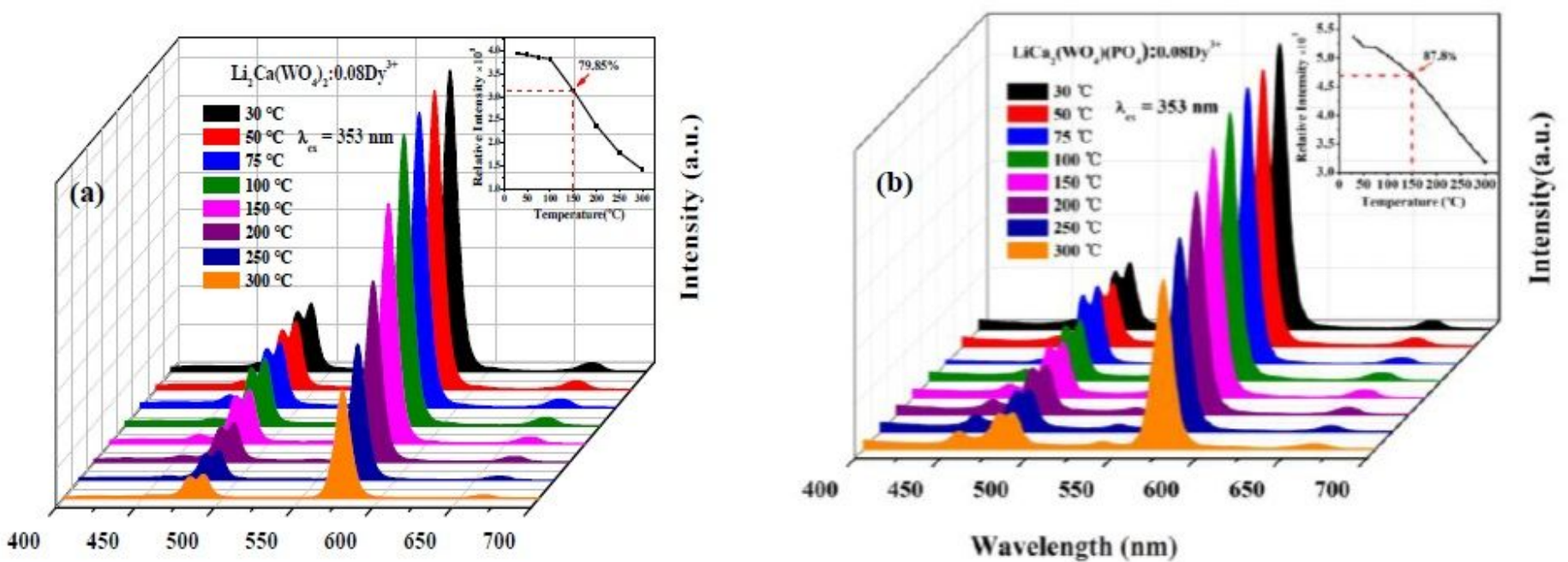

Wavelength (nm)

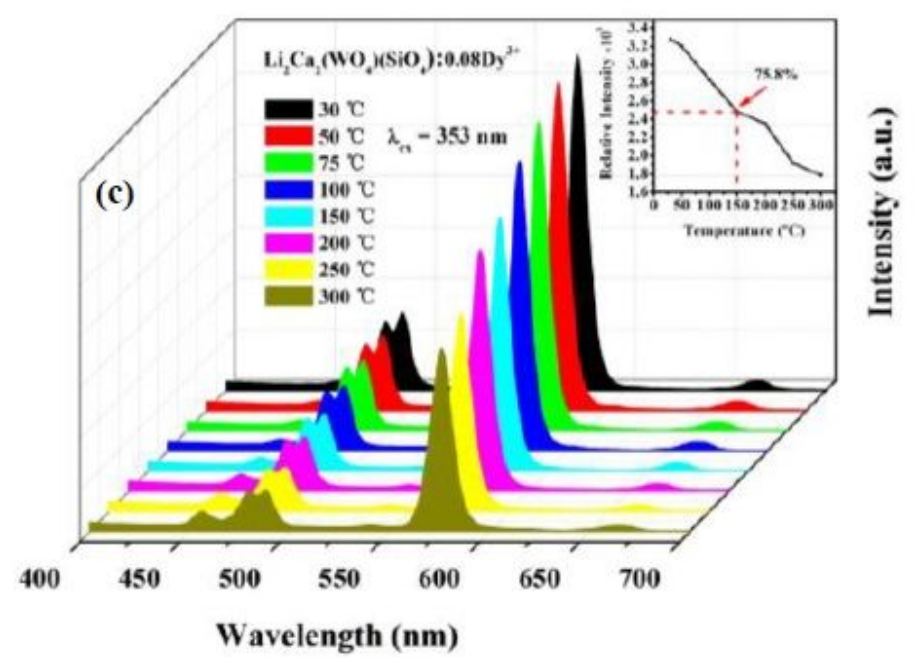

Figure 5

The PL spectra ( $\lambda$ ex $=353 \mathrm{~nm}$ ) of (a) Li2Ca(WO4)2:0.08Dy3+, (b) Li2Ca2(WO4)(SiO4): 0.08Dy3+ and (c) LiCa2(WO4)(PO4): 0.08Dy3+ samples under different temperatures in the range of 30-300 ${ }^{\circ} \mathrm{C}$, every inset shows the corresponding dependence of PL intensity of Dy3+ transition. 


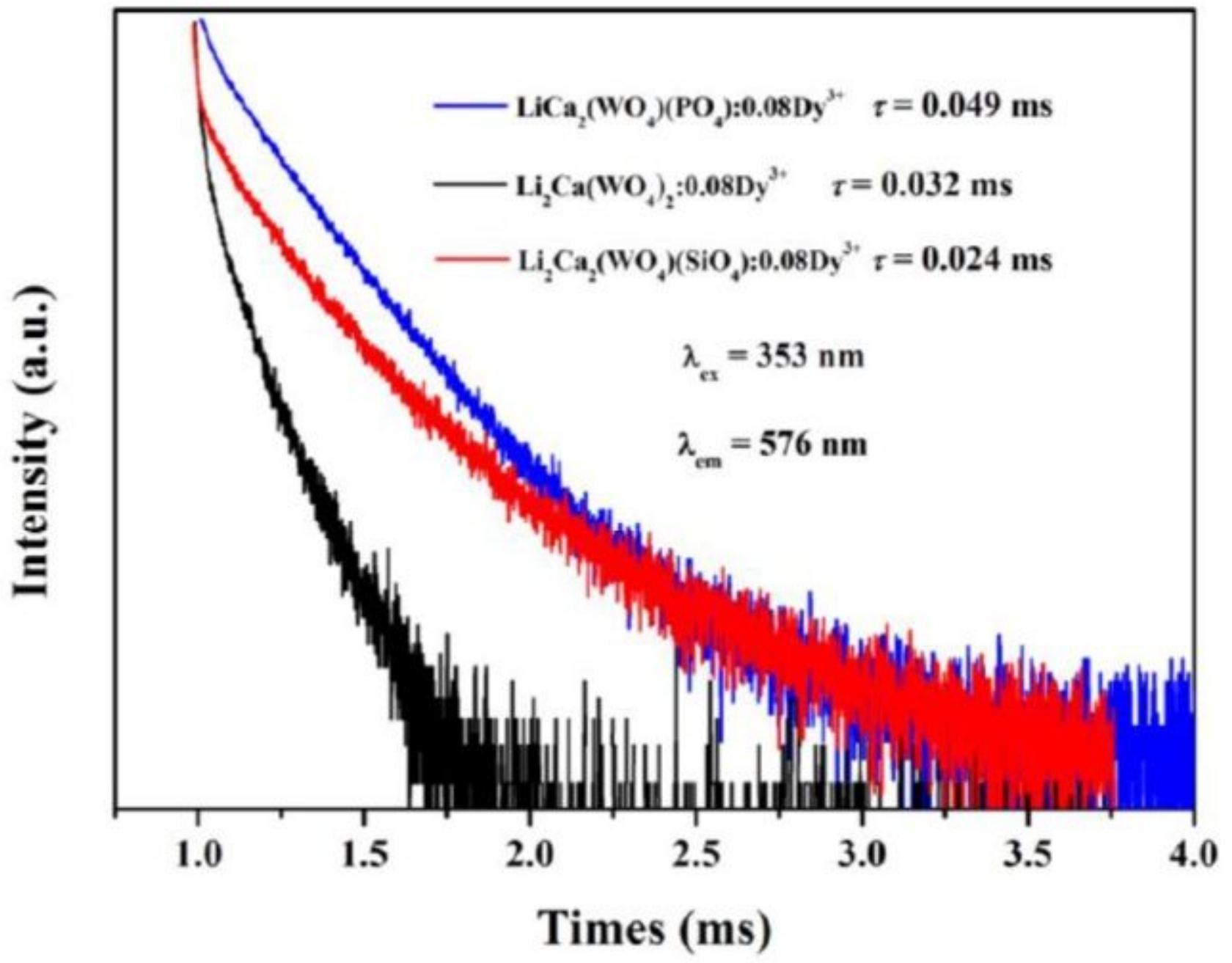

Figure 6

Decay curves and lifetimes ( $\tau$ ) of (a) Li2Ca(WO4)2:0.08Dy3+, (b) Li2Ca2(WO4)(SiO4): 0.08Dy3+ and (c) LiCa2(WO4)(PO4): 0.08Dy3+ samples $\lambda$ em $=576 \mathrm{~nm}$ खafter the pulsed excitation $(\lambda e x=353 \mathrm{~nm})$ at RT. 


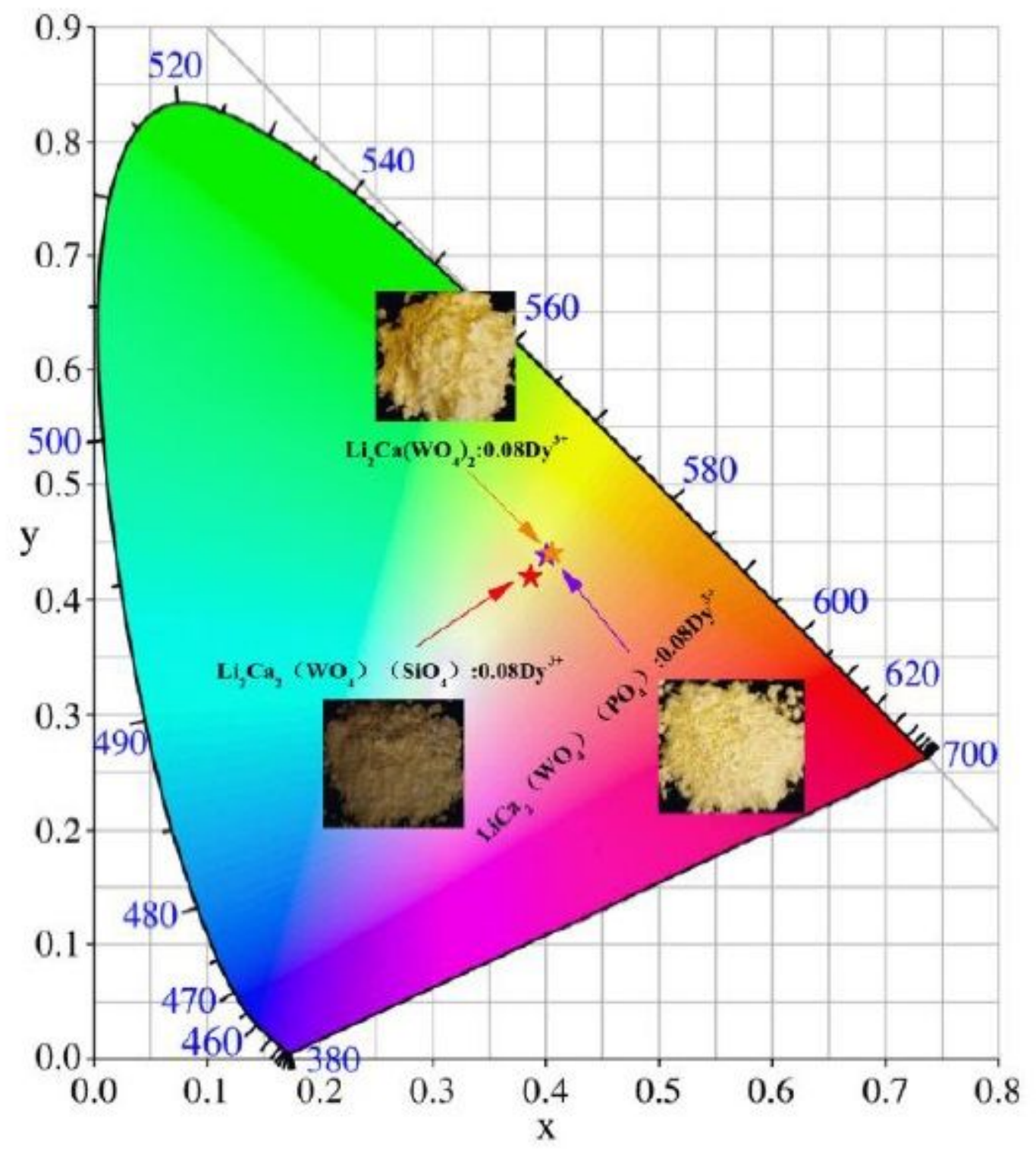

Figure 7

CIE color coordinates for the Li2Ca(WO4)2:0.08Dy3+ (orange star) , Li2Ca2(WO4)(SiO4): 0.08Dy3+ (red star) and LiCa2(WO4)(PO4): 0.08Dy3+ (purple star)at RT. The results are calculated using the emission spectra under $353 \mathrm{~nm}$ excitation. 